Florida A\&M University College of Law

Scholarly Commons @ FAMU Law

\title{
Bridging Race + IP: The Challenges and Potential of Utilizing Transdisciplinary Methods to Undo the Unbearable Whiteness of Intellectual Property
}

Deidre Keller

FAMU College of Law, deidre.keller@famu.edu

Follow this and additional works at: https://commons.law.famu.edu/faculty-books

Part of the Civil Rights and Discrimination Commons, Intellectual Property Law Commons, and the Law and Race Commons

\section{Recommended Citation}

Keller, Deidre, "Bridging Race + IP: The Challenges and Potential of Utilizing Transdisciplinary Methods to Undo the Unbearable Whiteness of Intellectual Property" (2020). Faculty Books and Book Contributions. 38.

https://commons.law.famu.edu/faculty-books/38

This Book Chapter is brought to you for free and open access by the Faculty Works at Scholarly Commons @ FAMU Law. It has been accepted for inclusion in Faculty Books and Book Contributions by an authorized administrator of Scholarly Commons@ @AMU Law. For more information, please contact paul.mclaughlin@famu.edu. 


\title{
Bridging Race + IP: \\ The Challenges and Potential of Utilizing Transdisciplinary Methods to Undo the Unbearable Whiteness of Intellectual Property ${ }^{1}$
}

\author{
By: Deidre A. Keller ${ }^{2}$ and Anjali S. Vats ${ }^{3}$
}

\author{
Get yours in this capitalistic system \\ So many caught or got bought you can't list them \\ How you gonna idolize the missing? \\ To survive is to stay alive in the face of opposition \\ Even when they comin', gunnin' I [stay in] position \\ $L$ 's known the mission since conception \\ Let's free the people from deception \\ If you looking for the answers then you gotta ask the questions \\ And when I let go, my voice echoes through the ghetto \\ Sick of men trying to pull strings like Geppetto \\ Why black people always be the ones to settle? \\ March through these streets like Soweto, $u h^{4}$
}

\author{
And we know we shall win \\ As we are confident \\ In the victory \\ Of good over evil ${ }^{5}$
}

\footnotetext{
${ }^{1}$ So far as the authors can tell, the first academic assertion of "unbearable whiteness" was in Carlin Romano, The Unbearable Whiteness of Being, 3 LINGUA FRANCA, July / August 1993, at 20; in referencing the unbearable whiteness of intellectual property, we join a chorus of critics noting the "unbearable whiteness" of various cultural and academic phenomenon. See, e.g, Sarah Sahim, The Unbearable Whiteness of Indie, Pitchfork (March 25, 2015), https://pitchfork.com/thepitch/710-the-unbearablewhiteness-of-indie/; https://indypendent.org/2011/05/the-unbearable-whiteness-of-being-how-changing-us-demographics-will-upend-white-peoples-sense-of-identity-history-what-it-means-for-the-rest-of-us/; Nyasha Mboti, The unbearable whiteness of white philosophers, Mail \& Guardian (March 8, 2017), https://mg.co.za/article/2017-03-07-the-unbearable-whiteness-of-white-philosophers; Elayne Puzan, The unbearable whiteness of being (in nursing), 10 Nursing Inquiry 193 (2003); Victor Ray, The Unbearable Whiteness of Mesearch, Inside Higher Ed (October 21, 2016), https://www.insidehighered.com/advice/2016/10/21/me-studies-are-not-just-conducted-people-coloressay; Jendella Benson, The unbearable whiteness of history, Media Diversified (January 27, 2017), https://mediadiversified.org/2017/01/27/the-unbearable-whiteness-of-history/; Fred Bonner, The unbearable whiteness of teaching, AFT Voices (March 23, 2016), https://aftvoices.org/the-unbearablewhiteness-of-teaching-ef6d8a55a3a3; Kayhan Parsi, The Unbearable Whitness of Bioethics: Exohorting Bioethicists to Address Racism, Bioethics.net (March 21, 2016), http://www. bioethics.net/2016/03/theunbearable-whiteness-of-bioethics-exhorting-bioethicists-to-address-racism/; André Carrington, The unbearable whiteness of science fiction, Open Democracy (May 13, 2016), https://www.opendemocracy.net/transformation/andr-carrington/whiteness-of-science-fiction.

${ }^{2}$ Associate Dean for Academic Affairs and Professor of Law, Claude Pettit College of Law, Ohio Northern University.

${ }^{3}$ Assistant Professor of Communication and African and African Diaspora Studies at Boston College and Assistant Professor of Law at Boston College Law School, by courtesy.

${ }^{4}$ Lauryn Hill, Forgive Them Father, The Miseducation of Lauryn Hill (Ruffhouse Records 1998) (emphasis added).

${ }^{5}$ Robert (Bob) Nesta Marley, War, Rastaman Vibration (Island Records 1976).
} 
Anjali was deep in thought when the calendar notification popped up on her phone: "Race + IP Methods Meeting with Deidre." ${ }^{6}$ The phone rang before she could even dial.

"Hey lady. How are you?"

"I'm pretty good! Just sent my book off to the press! I've been thinking a lot about the intersections between intellectual property and racial feelings today -- and, well, all the days recently. Knowledge politics feel heavy, especially in this political moment. I can't believe that my book is actually almost done after ten years. How are you?!?"

"That's great! We've been talking about that project for so long, I'm excited to read it! I'm okay. Behind, as usual.

So long! I'm sorry you're behind, I totally empathize. We clearly need to schedule a slow professor conversation sometime soon. Nothing like scheduling a meeting about doing less work to help us slow down. What's bogging you down? Grading?

"All the grading."

"Ugh. Writing?"

"All the deadlines.... Sigh!"

"Post-tenure ennui is real, I think. On the upside, we get to talk about this chapter today! I'm looking forward to thinking through methods questions with you."

"Same! Always happy to talk with my intellectual soulmate!"

"Aww, me too! On a related note, I just finished Charles Lawrence's 'The Word and the River,' which I know you love. I think I'm going to teach it in Critical Race Theory next semester. I'm interested to see what the students think of it. Maybe we could start by talking about it and the analytic work it does?"

"It's a tremendous piece. I definitely want to talk about it but I was hoping before we jump into specific texts, we could talk about how the method part of race and intellectual property is different from what we did in 'Critical Race IP.' ${ }^{8}$ For me, that article lays out the fundamental themes around race that arise in the context of copyrights, trademarks, patents, and other types of intellectual property law."

"It certainly does. For me, it also does a lot of method work too."

"Yes, but in that article we are doing Critical Race IP not explaining how to do it."

"Huh, I think I see what you're saying, Deidre. That's a really provocative point - and it gestures to the complicatedness of co-authorship, even with intellectual soulmates! In this case, I'm of the opinion that the thing speaks for itself, res ipsa loquitur if you will. We use practice as method in a way that follows many scholars of color. In the book Disidentifications, for example,

\footnotetext{
${ }^{6}$ In considering how we and others interested in investigating questions at the intersections of race and IP do that work, we thought it useful to embrace and utilize the storytelling methodology that Derrick Bell, Richard Delgado and other Critical Race Theorists use and advocate as a means of capturing the richness and complexity of the thoughts, conversations, epistemological positionings, and scholarly insights of people of color. The late Keith Aoki, who wrote and illustrated three comic books, including Bound by Law and Theft! A History of Music, demonstrates how storytelling can enrich the study of intellectual property rights, race, and social justice. See James Boyle, THEFT: A HISTORY OF MUSIC (2017); Keith Aoki \& James Boyle, Bound BY LaW? (Tales from the Public Domain) (2006).

${ }^{7}$ Charles R. Lawrence III, The Word and the River: Pedagogy as Scholarship and Struggle, 65 S. CAL. L. REV. 2231 (1992).

${ }^{8}$ Anjali Vats \& Deidré Keller, Critical Race IP, 36 CARdozo ARTS AND ENT. L. J. 735 (2018).
} 
the late José Esteban Muñoz talks about how queers of color perform in a way that negotiates the lived realities of ideology, by both acting within and remaking scripts about race and gender. ${ }^{9}$ Munoz certainly theorizes performance but he also sees unities in thinking and doing. And feminist scholars of color like Cherríe Moraga, Gloria E. Anzaldúa, and Chela Sandoval, who contemplate radical feminist methodologies, understand embodied practice as theory. ${ }^{10}$ Perhaps, we should begin by defining what we mean by methodology and why we need it? In a completely unsurprising turn of events, it seems we may have some disciplinary differences to contend with."

"Sure! For me, legal methodology is at least two things - research methods and analytical methods. These are related but distinct. For example, for the hashtag piece I am working on, ${ }^{11}$ I need to make sure that I identify all relevant sources of law - state statutes and jurisprudence pertaining to the rights of privacy and publicity, at a bare minimum, as well as the preeminent secondary sources engaging these - McCarthy's treatise, ${ }^{12}$ Jennifer Rothman's work, ${ }^{13}$ etc. Sound analytical methods are about what I do with those sources. There are various 'rules' about that pertaining to the value of precedent and the like. I needn't always adhere to those rules. But, in writing for law reviews and legal audiences, I do have to acknowledge the existence of those rules and explain the value of eschewing them if I choose to do so.

"That's an interesting way to think about method. It sounds like our legal methods class in law school, where we learned about hierarchies of legal authority. But l've always thought of that structuring of legal authority as about the practice of law instead of the method of law. That's certainly a disciplinary difference between law and ethnic studies, or even Critical Race Theory. The concept of method gets even more interesting if we talk about studying what Sandoval calls 'oppositional consciousness' to authority itself. ${ }^{14}$ Thinking about legal authority and oppositional consciousness at the same time is no easy task, as Richard Delgado points out so well in the "Imperial Scholar."'15 In many ways, CRT is ideologically anti-hierarchical. That's not to say that it's not important to think about legal authority, even he concedes that it matters. But I see questions of choosing which sources to cite and how as included in the project of understanding law as a site for the cultural negotiation of race and power."

"Two things. First, this is where Lawrence is really instructive, right. He reminds us that teaching, scholarship, and praxis, are different aspects of one thing - the Word. ${ }^{16}$ This is

\footnotetext{
9 José Esteban Muñoz, Disidentifications: Queers Of Color And The PeRformance Of Politics (1999).

${ }^{10}$ Chela Sandoval, Methodology OF THE OpPressed (2000); Cherríe Moraga \& Gloria Anzaldúa, eds., THIS BRIDGE CALLED MY BACK: WRITINGS BY RADICAL WOMEN OF COLOR (1981).

${ }^{11}$ Deidré A. Keller, Will I Be the Next Hashtag (2018) (unpublished manuscript) (on file with author).

12 J. Thomas McCarthy, THE RIGHTS OF PuBliCITY AND PRIVACY, 2018.

${ }^{13}$ See, e.g., Jennifer E. Rothman, The Inalienable Right of Publicity, 101 GeORGETOWN L. J. 185 (2012).

14 Chela Sandoval, Methodology OF THE OPPRESSED (2000).

${ }^{15}$ Richard Delgado, The Imperial Scholar, 132 U. PA. L. REV. 561 (1984).

${ }^{16}$ Lawrence, supra note 7 at 2238 ("I feel an immediate kinship with the tradition that Harding describes and names 'the Word.' It is a tradition of teaching, preaching, and healing; an interdisciplinary tradition wherein healers are concerned with the soul and preachers with the pedagogy of the oppressed; a tradition that eschews hierarchy in the face of the need for all of us who seek liberation to be both teachers and students. The Word is an articulation and validation of our common experience. It is a
} 
fundamental to CRT and to race and IP methodology, I think, because if we are theorizing in ways that fail to attend to the very real consequences our theorizing could have in the world then we're not doing it right. ${ }^{17}$ Ditto for teaching. One of the challenges of bringing a critical race lens to intellectual property law is that while sound legal research and analytical methods are imperative in helping clients solve problems, they are often inadequate tools for critiquing the law. When the project is critiquing the law, as it is whenever engaging with questions at the intersections of race and intellectual property, I necessarily have to branch out from the specific area of the law I am interested in critiquing to engage the larger questions. To stay with the hashtag piece example, in order to even ask this question about whether the legal concepts we ordinarily deploy when a client wants to stop the use of a name or likeness are up to the task of aiding a grieving family who has lost their child at the hands of a police officer, I have to do what Derrick Bell was suggesting in Faces at the Bottom of the Well, listen to those for whom these laws were not necessarily written and who these laws don't often serve well. ${ }^{18}$ To do those questions justice always requires historical contextualization and an awareness of the continuing potency of race."

"Absolutely! This is the place where we can definitely find a bridge between our two approaches. The Race Crits -- I so love that name for practitioners of Critical Race Theory -often use methods external to law, drawn from insights gained from the Civil Rights Movement and the rise of newly institutionalized disciplines like ethnic studies and Black Studies. I start from the methodological presumption that we have to dig into the specific and situated histories, rhetorical constructions, and every day, lived implications of "the law," a term that Rosemary Coombe pokes a bit of fun at by saying that you only ever hear people talking about it as a discrete object at humanities conferences. ${ }^{19}$ There's so much going on culturally before, during, and after a specific law comes into being! For instance, as Mary Dudziak points out, in a now canonical study in CRT, we have to understand the Cold War and McCarthyism as a major part, if not definitive factor, in the successful passage of the Voting Rights Act. ${ }^{20}$ Similarly, intellectual property law is driven by and invested in certain kinds of racial outcomes, which we have to actively name. Studying history, language, and cultural practices can uncover how race gets baked into the IP cake, so to speak. Coombe makes this argument in The Cultural Life of Intellectual Properties, though with more emphasis on the culture part than the race part. ${ }^{21}$ When we read race scholars in conjunction with intellectual property scholars, we see that

vocation of struggle against dehumanization, a practice of raising questions about reasons for oppression, an inheritance of passion and hope.").

17 Mari Matsuda, Where is Your Body? Protest and Social Transformation, in WE THE PEOPLE 24 (1996)

("As José Bracamonte pointed out in his foreword to the Harvard Civil Rights - Civil Liberties Minority

Critique of Critical Legal Studies, people of color cannot afford to indulge in deconstruction for its own sake. Our critique is goal oriented. The work produced by scholars of color ties pragmatic law reform to criticism and radical theory in a way no one on the jurisprudential scene, except for our feminist sisters, is doing.").

18 Derrick Bell, Faces at the Bottom of the Well: The Permanence of Racism (1992).

${ }^{19}$ Rosemary J. Coombe, Critical Cultural Legal Studies, 10 YALE J. OF L. \& THE HUMANITIES 463, 478 (1998).

${ }^{20}$ Mary L. Dudziak, Cold WAR CIVIL RIGHTS (2011).

${ }^{21}$ Rosemary J. Coombe, The Cultural Life of InTEllectual Properties: Authorship, Appropriation, AND THE LAW (1998). 
neither race nor law are fixed; both evolve over time in ways that can strengthen or weaken racial hierarchies. And, of course, as numerous race scholars have demonstrated, whiteness is an invisible norm which we have to actively work to make legible." 22

"Of course, I agree with much, if not all, of that. In thinking through how we maintain multidisciplinarity and speak to audiences in the humanities, social sciences, education, and law -- all of whom come with a range of methods understanding from their own disciplines -- part of what I am wondering is how we do exactly what you mentioned, build bridges from where they are to the types of methods we'd suggest they engage. I'll admit that in my law teaching, I have never taught 'methods,' per se. I do some case synthesis in Property and some research question / thesis development in my seminars but none of that is labeled 'methods' for the students. Because my own context is legal teaching and practice, I am perhaps particularly attuned to the type of methods training legal readers are likely to have had. So, you'll remember that in our Legal Methods class in law school, we didn't address critical methodologies, at all. In fact, all I remember learning about in that class was rule synthesis through the attractive nuisance cases and Chevron. ${ }^{23}$ I remember a lot of Chevron.... In preparing for this conversation I went back and looked at the textbook that we were taught out of for that class and that edition did contain chapters on both Critical Race Theory and Feminist Jurisprudence. ${ }^{24}$ I don't remember ever getting to those chapters. Do you?"

Anjali laughed, "I'm grateful that Chevron is just a gas station to me these days! I certainly do not remember talking at all about CRT or feminist jurisprudence. In fact, the first time I formally studied CRT was at the University of Washington during my LLM in intellectual property law! Clearly, l've always had some interdisciplinary tendencies, which are as much about cultivating survival skills as they are about interest. In any event, I had much more opportunity to study race in graduate school than I ever did in law school. I'll say, though, it's not easy to be an interdisciplinary scholar of race and law, especially in a fast moving area like intellectual property. It is incumbent upon scholars that do interdisciplinary work to keep up on their race theory as well as their case law, especially given some of the prejudices about race work not being 'real scholarship.'.

Now is definitely not the time for a tangent about racial double standards in academia, though, so let me get back to the method question. I really like that you invoked the metaphor of building bridges, in part because the edited collection that I was referring to above, by Moraga and Gloria E. Anzaldúa, is called The Bridge Called My Back. We talked a lot about method in my program, which was helpful as humanists are often accused of 'just saying their opinions.'

\footnotetext{
${ }^{22}$ Anjali S. Vats, The Color of Creatorship: InTELLECtUAL Properties, RaCial SCRIPTS, AND the MAKING OF AMERICANS (forthcoming at Stanford University Press); see also, Charles W. Mills, Racial Contract 1 (1997) ("White supremacy is the unnamed political system that has made the modern world what it is today. You will not find this term in introductory, or even advanced, texts in political theory. . . . And this omission is not accidental. Rather, it reflects the fact that standard textbooks and courses have for the most part been written and designed by whites, who take their racial privilege so much for granted that they do not even see it as political, as a form of domination. Ironically, the most important political system of recent global history - the system of domination by which white people have historically ruled over and, in certain ways, continue to rule over nonwhite people - is not seen as a political system at all.").

${ }^{23}$ Chevron U.S.A., Inc. v. NRDC, 467 U.S. 837 (1984).

${ }^{24}$ Eva H. Hanks, Michael E. Herz \& Steven S. Nemerson, ElementS OF LAW (1994).
} 
As a sidenote, I'm of the opinion that questions of method are often actually racial anxieties in disguise -- but that's also a conversation for another day. I tend toward a mixed method approach which includes studying histories, material structures, culture, rhetorics, embodied performances, and racial feelings around legal regimes. One of the hardest parts of writing my monograph was figuring out which methods were appropriate and useful for the task at hand. ${ }^{25}$ We forget, sometimes, that different methods allow us to ask and answer different kinds of questions. Scholars like Funmi Arewa, ${ }^{26}$ Sonia Katyal, ${ }^{27}$ Boatema Boateng, ${ }^{28}$ Rayvon Fouche, ${ }^{29}$ KJ Greene, ${ }^{30}$ and Kembrew McLeod, ${ }^{31}$ showcase how different methods can yield very different research projects. Their methods, which include international legal study, philosophical inquiry, ethnographic study, archival work, contract analysis, and interviews, among other methods, help us to think deeply about the intersections between race and law. -- who force us to engage creatively with method. Both Race + IP conferences were helpful too in demonstrating that there is an abundance of space for methodological innovation in studying intellectual property and race concurrently. For instance, the conversations at Race + IP 2019 about algorithmic bias and Census data opened new methodological doors for me.

Let me pause there. I obviously have a lot of thoughts about method. Let me shift gears here so we can focus a bit. Deidre, keeping in mind that readers may have wildly different levels of experience and knowledge with the topics l've mentioned, what do you think we need to convey to them about race and intellectual property methods?"

"First, we need to be absolutely clear that intellectual property is about more than law. Media studies, rhetoric, and ethnic studies readers will very likely have encountered the concept of law and culture as mutually constitutive before. ${ }^{32}$ For those readers we may only need to build a little bridge from what they already know to the specifics of intellectual property law. For legal readers who may well have been taught that the law is its own world, separate and apart from culture and politics, ${ }^{33}$ we'll likely have to build a bigger bridge. One way to try to get

\footnotetext{
${ }^{25}$ Vats, supra note 22.

${ }^{26}$ See, e.g., Olufunmilayo B. Arewa, From J.C. Bach to Hip Hop: Musical Borrowing, Copyright and Cultural Context, 84 N.C. L. REV. 547 (2006).

27 See, e.g., Sonia K. Katyal, Trademark Intersectionality, 57 UCLA L. REV. 1601 (2010).

${ }^{28}$ Boatema Boateng, THE COPYRIGHT THING DOESN'T WORK HERE: AdINKRA AND KENTE CLOTH AND INTELLECTUAL PROPERTY IN GHANA (2011).

${ }^{29}$ See, e.g., Kara W. Swanson, Banking ON THE Body: The MARKET In BLOOd, MiLK, AND SPERM IN Modern AMERICA (2014); Rayvon Fouché, BLACK INVENTORS IN THE AGE OF SEGREGATION (2003).

${ }^{30}$ See, e.g., Peter K. Yu, What the Treatment of African-American Artists Can Teach About Copyright Law, in INTELLECTUAL PROPERTY AND INFORMATION WEALTH: ISSUE AND PRACTICES IN THE DigitAL AgE (2006).

${ }^{31}$ DVD: Copyright Criminals (Independent Lens 2010) (available at http://www.pbs.org/independentlens/copyright-criminals/film.html).

32 See, e.g., Christy Collis \& Jason Bainbridge, Popular Cultures and the Law 19 ContInUUM: J. OF MEDIA AND CULTURAL STUDIES 159 (2005).

${ }^{33}$ See, e.g., James Boyd White, Law as Rhetoric, Rhetoric as Law: The Arts of Cultural and Communal Life, 52 U. CHI. L. REV. 684, 685 (1985) ("the law is at present usually spoken of (by academics at least) as if it were a body of more or less determinate rules, or rules and principles, that are more or less perfectly intelligible to the trained reader. Law is in this sense objectified and made a structure. The question "What is law?" is answered by defining what its rules are, or by analyzing the kinds of rules that characterize it.").
} 
everyone on the same page is to consider some work by legal scholars that is demonstrative of the iterative relation between intellectual property law, specifically, and culture. Coombe's work comes to mind immediately. Keith Aoki speaks directly to the mutually constitutive nature of law and intellectual property in a book chapter called, The Stakes of Intellectual Property Law. ${ }^{34}$ The other piece that comes to mind is D.D. Troutt's "A Portrait of the Trademark as a Black Man." ${ }^{35}$ I think Troutt's piece is particularly helpful. It makes the theoretical claim regarding the interrelation between culture and IP in broad strokes and then applies that claim to address a big picture intellectual property question - whether IP rights expansion is a good thing from the perspective of human flourishing - all while considering how race complicates these questions. What do you think?"

"I love that piece! You know me, I'm inclined to suggest reading everything, because, well I'm a child of the 80s and I watched a lot of Reading Rainbow. I'd suggest 'Selling Women' by Rayvon Fouche and Sharra Vostral. ${ }^{36}$ It does a great job of highlighting how culture informs law, in a profoundly intersectional consideration of patent law. I also love Minh-Ha Pham's new work on copynorms and racial feelings. It might feel like a stretch to some of the legal readers but it really highlights how cultural and affective commitments around race are central to making law. ${ }^{37}$ And of course, Madhavi Sunder's From Goods to a Good Life is a great and foundational piece in this space. ${ }^{38}$ I'm always struck by Siva Vaidhyanathan's observation in the document Copyright Criminals that courts in the 1990s were not interested in learning about the creative processes of Black men. It succinctly sums up everything I feel about the position that courts ended up taking toward hip hop - which is very much about race and culture, not "objective" law. That's just the tip of the iceberg, really, in terms of scholarship.

"Deidre, what else do we want readers to know about race and intellectual property? I want it to be clear to them that these areas of law are about so much more than dry legal concepts leveraged by wealthy lawyers on behalf of corporations."

"For some, this may be their first foray into critical race anything. So, l'd start with some basics about critical race methodologies and highlight the commitment to narrative and counternarrative as central to the critical race theory project. Daniel Solorzano and Tara Yosso do a nice job of articulating a critical race methodology, the main elements of which are (1) centering race and racism in all aspects of the research and praxis while making sure to conduct intersectional analysis so as not to lose sight of class, gender, and other axes of oppression; (2) challenging traditional research practices, l'd say especially the notion of the researcher, teacher, lawyer, as the objective expert; (3) offering solutions, that is, eschewing the notion of theorizing for theory's sake in favor of focusing on solutions to the real-world problems faced by people of color; (4) viewing the racialized, classed, and gendered experiences of clients,

\footnotetext{
${ }^{34}$ Keith Aoki, The Stakes of Intellectual Property Law, in THE POLITICS OF LAW: A PROGRESSIVE CRITIQUE 259 (David Kairys ed., 3d ed. 1998).

35 David Dante Troutt, A Portrait of the Trademark as a Black Man: Intellectual Property, Commodification, and Redescription, 38 U.C. DAVIS L. REV. 1141 (2005)

${ }^{36}$ Rayvon Fouché \& Sharra Vostral, "Selling" Women: Lillian Gilbreth, Gender Translation, and Intellectual Property, 19 AM. U. J. OF GENDER SOC. POL'Y 825 (2011).

${ }^{37}$ Minh-Ha Pham, Feeling Appropriately: On Fashion Copyright Talk and Copynorms, 51 Soc. TEXT 34 (2016).

${ }^{38}$ Madhavi Sunder, From Goods to A Good Life: INTELleCtual PROPERTY AND Global Justice (2012).
} 
students, and others as a rich source for articulating relevant questions and working toward viable solutions; and (5) interdisciplinarity. ${ }^{39}$ They're writing about education but I do think that the methodological framework they posit is transferable to many contexts and is certainly a pretty concise description of what I am aiming to do when I am working on race and IP issues.

"That sounds like a great summary of the unifying principles of CRT! And I agree, situating critical race practice is super important. For me the intersections of race and intellectual property are very much about identifying and critiquing the normalization and propertization of whiteness, as we alluded to before. Much of the race critique around intellectual property has involved identifying the tendency of the area's organizing concepts to facilitate white colonization of knowledge production. For instance, Madhavi Sunder and Anupam Chander authored a really important piece on the "public domain" and the idealization of that space as one that solves the problems of privatization of knowledge. ${ }^{40}$ As a wealth of literature has demonstrated, the public domain itself is a raced and colonized space, one that is shaped by histories of property and colonialism. This, of course, brings us back, to the idea of ideology and, relatedly, storytelling. Intellectual property is fundamentally about competing narratives concerning the ownership of knowledge. People like Vandana Shiva, for instance, show how indigenous peoples have historical rights in knowledge that are erased by legal regimes. ${ }^{41}$ We can make similar arguments about the racial investments of other core concepts in intellectual property law, like copyright's understandings of 'originality' as a means of preventing people of color from protecting their creative works, patent law's colonization of indigenous knowledge through doctrinal understandings of 'novelty,' and trademark law's use of "dilution" as a tool of policing social norms. ${ }^{42}$ As we dig into intellectual property's doctrinal relationship to whiteness, we also begin to see how knowledge protection is structurally embedded in a system that Cedric Robinson refers to as racial capitalism. ${ }^{43}$ I also really like the (re)turn in contemporary race and ethnic studies scholarship toward racial feelings. In order to understand how intellectual property is raced, we really need to understand how it is structured by public feelings about race.

Let me give an example. If we start thinking about race in relation to the sampling cases of the 1990s, then we have to think about how racial panics around fear of crime and moral panics around obscenity influenced the way that people think about Black creatorship specifically originality - in music. That narrative of course, flips history on its head. In actuality, white musicians had stolen from Black blues and jazz singers, which suggests, perhaps, that hip-hop artists deserved a bit of space to be creative with samples. Courts went in precisely the

\footnotetext{
39 Daniel G. Solózarno and Tara J. Yosso, Critical Race Methodology: Counter-Storytelling as an Analytical Framework for Education Research 8 QUALITATIVE INQUIRY 23 (2002).

${ }^{40}$ Anupam Chander and Madhavi Sunder, The Romance of the Public Domain, 92 CALIF. L. REV. 1331 (2004).

${ }^{41}$ Vandana Shiva, BiopiRAcy: the Plunder of NATURE AND KNOWLedge (1999).

42 Richard Schur, "Legal Fictions: Trademark Discourse and Race," in AFRICAN AMERICAN CULTURE AND LEGAL DiscouRSE, ed. Lovalerie King and Richard L. Schur, 1st ed (New York: Palgrave Macmillan, 2009).

${ }^{43}$ Cedric J. Robinson, Black MarXISM: The Making OF tHe Black Radical TRAdition 9 (2000); see also Robin D. G. Kelley, What did Cedric Robinson Mean by Radical Capitalism?, Boston Review (Jan. 12, 2017), http://bostonreview.net/race/robin-d-g-kelley-what-did-cedric-robinson-mean-racial-capitalism.
} 
opposite direction, in cases like Grand Upright Music, ${ }^{44}$ and started talking about hip hop artists as thieves and villains. To me, Biz Markie's loss is as much about the racial sentiments about Black criminality at the time as it is about the samples. Everyone knows that Biz Markie's song neither sounds like Gilbert O'Sullivan's nor appeals to the same audience. If anything, Biz Markie created a new market among copyright nerds for O'Sullivan's song! There's no question in my mind that Biz Markie's sound was totally new and original. But courts weren't willing to make space for people of color to create, at least not with economic incentive to do so. They were not interested in Black men's creativity.

While McLeod doesn't get at this directly in his work, his interviews with musicians tell a story about how copyright law gets structured through racial capitalism, i.e. the decision to insist that Black artists pay for using samples even though doing so was largely unprecedented, and racial feelings, i.e. the intense sentiments of anti-Blackness in the nation targeted specifically at urban youth. There's a lot of layers here. We have to dig deep using anti-racist and anti-colonial lenses if we want to think about equitable and inclusive intellectual property."

"That all makes good sense to me. And, actually, it wasn't until I read Grand Upright Music alongside Rogers $v$. Koons, ${ }^{45}$ which was decided by the same district court as Grand Upright Music just one year earlier, that I came to see the extent to which race is at play in Grand Upright Music. While the two cases are factually very similar, with Defendants conceding use of works owned by the Plaintiffs, the rhetoric in Grand Upright Music is drastically more moralistic. I am still struck by the judge in Grand Upright's decision to refer the case to the State's attorney for prosecution. Of course, no such referral is made in Koons. And, in fact, I can find no other case referring such Defendants for criminal prosecution."

"Absolutely. The recommendation for criminal prosecution, i.e. 'sterner measures' in Judge Frank Duffy's words, is really out of left field and moralistic in a way that we can really only understand as being about refusing to acknowledge Black creativity as anything other than theft. Jeff Koons is a fraught character too, because of the earlier cases in which he failed to successfully navigate the parody/satire distinction. Once he figured out the rules, he won in court. I'm not sure that the same would be true of Biz Markie - and I certainly don't think that Campbell v. Acuff-Rose somehow remedies the outcome in Grand Upright, racially speaking. ${ }^{46}$ Aoki tells a similar story in his comic book Theft! The History of Music. ${ }^{47}$ And of course, we see the exploitation of Black and Brown artists at the hands of white artists often, historically speaking. Sunder discusses the theft of Wimoweh, the song from the Lion King. ${ }^{48}$ There are other examples too. It's important to note, though, when speaking about method in this area that we are talking about much more than just outcomes in cases. We can't just make a chart of when Black and Brown litigants beat white litigants to understand how race and (neo)colonialism work in intellectual property law. There's much more to the story."

"Or, as is more often the case, when Black and Brown litigants are beaten by white litigants. Or, as is still more often the case, when white litigants are deemed free to do

\footnotetext{
${ }^{44}$ Grand Upright Music, Ltd v. Warner Bros. Records Inc., 780 F. Supp. 182 (S.D.N.Y. 1991).

${ }^{45}$ Rogers v. Koons, 751 F. Supp. 474 (S.D.N.Y. 1990).

${ }^{46}$ Campbell v. Acuff-Rose Music, Inc., 510 U.S. 569 (1994).

${ }^{47}$ Keith Aoki, James Boyle, and Jennifer Jenkins,THEFT: A HISTORY OF Music (2017).

${ }^{48}$ Sunder, supra note 38.
} 
something that Black litigants have long been understood as not being free to do. That case about Madonna's Vogue is nothing short of mind-boggling in light of Bridgeport Music." 49

"Exactly! That case is emblematic of this area of law's racial hypocrisy for so many reasons! But, understanding each of those cases individually doesn't quite get you there, right. There's a set of beliefs that underlies doctrine; we really have to think about doctrinal racial dynamics and how they work in practice. This is about doctrinal commitments and ideologies, which is why an argument like the one that Justin Hughes and Robert Merges make in their recent law review article on the value of Black intellectual properties doesn't get to the heart of the difficulties with copyright law. ${ }^{50}$ Method -- especially race-focused method -- very much needs to be about thinking culturally and structurally rather than individually. ${ }^{51}$ Racism and colonialism are institutional systems. That's why we need those methods that come from other disciplines."

"Anj, can you hold on for one second? There is a student at my door."

"Sure. I have another fifteen minutes before I have to run myself."

"O.K. Thanks, lady. I'll be right back."

While Deidre tended to her student, Anjali gave some thought to what it might be like to teach a Race \& IP methods course. Scaffolding such a course for a mixed audience of law students and graduate students, in the social sciences and humanities, would be a complicated task. Introducing CRT was a difficult task on its own. Teaching concepts like "racial capitalism" and "racial feelings" as tools to think about case law was a formidable yet intriguing challenge.

Deidre returned, "Sorry about that, lady. The student that just came in is in academic trouble. And, she's a woman of color and a mom. I've been wracking my brain about how I can help her and coming up empty. Her dropping in does remind me that I wanted to ask whether you think it would be productive to consider how our identities as women of color impact our work in this space. It is definitely something that I think about quite a bit in both my teaching and my writing. I mean, when a respected figure in your field like Richard Posner refers to the work you are building upon as 'the lunatic core, ${ }^{52}$ it's hard not to spend some time thinking about how your research into issues that concern race is likely to be received or what impact doing that research has on your career prospects."

"I certainly understand that. You know me, l've always been unapologetic about my race work. Basically, I figured that I would do me and the right employers would find me. I was defiant in my 20s, though! And I definitely had privileges that allowed me to be that way. I like to think I've mellowed out, at least a little bit, in my advanced age."

\footnotetext{
${ }^{49}$ VMG Salsoul, LLC v. Ciccone 824 F.3d 871(9th Cir. 2016) (holding that sampling an existing sound recording may well constitute a de minimis use not subject to copyright infringement liability in spite of Bridgeport Music, Inc. et al. v. Dimension Films, et al. 410 F.3d 792 (6th Cir. 2005) which had held that the de minimis use exception categorically did not apply to samples of sound recordings).

50 Justin Hughes and Robert P. Merges, Copyright and Distributive Justice, 92 NOTRE DAME L. ReV. 513 (2016).

51 Stuart Hall, Race, Articulation, and Societies Structured in Dominance, in BLACK BRITISH CULTURAL STUDIES: A READER 16 (1996); see also, John A. Powell, Structural Racism: Building Upon the Insights of John Calmore, 86 N.C. L. REV. 791 (2008).

52 Richard Posner, The Skin Trade, The New Republic 40 (Oct. 13, 1997) ("Every intellectual movement has a lunatic fringe. Radical legal egalitarianism is distinguished by having a rational fringe and a lunatic core. The latter is constituted by the critical race theorists ....").
} 
Deidre laughed, "Defiant is one way to put it.... Let's table how far down that particular rabbit hole of we want to go in this methods piece for now. I know you said you'd need to get going soon so what else would you like to tackle today?"

"Ha! You know me, I have an endless list of topics related to methods that I want to tackle. We've barely scratched the surface! But while we're on the subject of reception within law schools, l'll admit, I'm skeptical that lawyers, or even law professors and students, will be willing to take up these race methods in studying intellectual property law. I taught a class at UC Davis School of Law called Race, Intellectual Properties, and National Identities and, while I think the students found a lot of the scholarship we read, including methodologically, enlightening and helpful, I also think many of them were left wondering how to incorporate all this theory into their legal practice. How do you think we can persuade lawyers -- and law schools too -- that this material is important, particularly at this moment when race scholars are very rightfully concerned with addressing police brutality, mass incarceration, and Black death as well as electing a progressive president?"

"That's a really interesting question. Ta-Nehisi Coates addresses the relationship between black art and black death in Between the World and Me. He says:

Contrary to this theory [that only the west mattered], I had Malcolm. I had my mother and father. I had my readings of every issue of The Source and Vibe. I read them not merely because I loved black music--I did-- but because of the writing itself. Writers like Greg Tate, Chairman Mao, dream hampton--barely older than me--were out there creating a new language, one that I intuitively understood, to analyze our art, our world. This was, in and of itself, an argument for the weight and beauty of our culture and thus of our bodies. And now each day, out on the Yard, I felt this weight and saw this beauty, not just as a matter of theory but also as demonstrable fact. And I wanted desperately to communicate this evidence to the world, because I felt--even if I did not completely know--that the larger culture's erasure of black beauty was intimately connected to the destruction of black bodies. ${ }^{53}$

KJ Greene's work also makes this argument about the relationship between misuses of black art and the dehumanization of Black people. I'm thinking specifically of Intellectual Property at the Intersection of Race and Gender as a good example of the value of engaging with CRT. ${ }^{54}$ An interesting counterpoint for legal readers might be Tonya Evans' Sampling, Looping, and Mashing Oh My. ${ }^{55}$ It engages with similar questions at the intersections of race, music, and intellectual property as Greene's piece but from a strictly doctrinal perspective; that is to say, without employing a CRT framework. I think putting those pieces into conversation with each other could prove really productive as a first step for legal audiences interested in the questions at these intersections.

\footnotetext{
53 Ta-Nehesi Coates, BETWEEN THE WoRLD AND ME 44 (2015).

${ }^{54}$ K.J. Greene, Intellectual Property at the Intersection of Race and Gender: Lady Sings the Blues, $16 \mathrm{~J}$. OF GENDER, SOC. POL'Y, \& THE L. 365 (2007).

55 Tonya M. Evans, Sampling, Looping, and Mashing. . O Oh My!: How Hip-Hop Music is Scratching More than the Surface of Copyright Law, 21 FORDHAM INTELL. PROP. MEDIA \& ENT. L. J. 843 (2011).
} 
Funny enough, I think this brings us full circle to Lawrence's The Word and the River. That piece makes an important contribution to race scholarship by articulating the relationship among teaching, praxis, and pedagogy. But it also offers another important, perhaps imperative, contribution to our discussion of doing race and intellectual property work - the fraught but useful idea of hope. Lawrence says:

One can also speak of dreams as an expression of hope for the future or as an imagining of new possibilities. When Martin Luther King, Jr., spoke of having "a dream," he conveyed this meaning. The meaning contains both an optimism for a better future and a vision of how that future will be better. King's dream is inspirational in two senses: Its message is infectious and encouraging and its origin is spontaneous, a seemingly divine imparting of knowledge, a brainstorm. Both of these elements of the wakeful dream are important to the practice of the Word. The sustained struggle for liberation from racial oppression must be fed by a faith in ultimate victory. A true revolution must be guided by ideas that do not arise from old paradigms of thought.

To say that an oppressed people has a special capacity for hope may seem paradoxical, but the slave knows intuitively that the system of slavery is vulnerable and that its destruction is inevitable. . . .

[M] uch of our faith in the inevitability of the victory of good over evil is exactly that: a faith. . . . ${ }^{56}$

As an aside, Lawrence is echoing my favorite song of all time there $\ldots . .{ }^{57}$ I digress. Lawrence continues:

[T]his faith in the ultimate demise of racist structures does not depend upon a belief in God. Rather, our morality rests in our personal knowledge of the subordinator's fear and disease. . . . We know that racism ill serves the racists. We are hopeful because our vision, our morality, is a vision that will free us all. ${ }^{58}$

Lawrence makes clear that dreaming is no mere emotional or mental exercise. It is, instead, the way we begin to contemplate worlds that have never been. That's something that Bell does too when he tells his story about a Black Atlantis that -- spoiler alert -- sinks back into the ocean. ${ }^{59}$ It's the possibility of liberation that matters and the exercise of imagining that is productive. Racial justice isn't some past we can return to. Rather, it is a future that we can only get to if we can think it, dream it into being, plan a course to get there, and sustain ourselves and each other along the way.

\footnotetext{
${ }^{56}$ Lawrence, supra note 7, at 2295-96.

${ }^{57}$ Marley, supra note 5.

${ }^{58}$ Lawrence, supra note 7, at 2296.

${ }^{59}$ Derrick Bell, Afrolantica (1997).
} 
Speaking of sustaining ourselves, I know you have to go and my grumbling belly suggests I ought to go too."

"I think I can hear your grumbling belly from over here! We're leaving some pretty important questions on the table, particularly the question of how to navigate this work as a scholar and woman of color. l'll definitely be thinking about that before we talk next."

"I agree! I'm not overly concerned about leaving questions on the table. As the inestimable Ms. Lauryn Hill says, 'If you're looking for the answers, then you gotta ask the questions...."60

Laughing, "you're determined to get that into some piece of legal writing, aren't you?"

"Of course! Listen, if Lawrence can channel Uncle Bob, I can reference Ms. Lauryn Hill....

"Uh huh.... On that note, talk to you soon!.

"Talk soon, lady."

${ }^{60}$ Hill, supra note 4. 